\title{
Spectrophotometric Determination of Tranexamic Acid by Azo-Dye Formation-Application to Pharmaceutical Preparations
}

\author{
Mohamed Y. Dhamra \\ Department of Chemistry / College Of Education \\ University of Mosul
}

Received

05 / 04 / 2010
Accepted

21 / 07 / 2010

\section{الخلاصة}

وصفت طريقة طيفية وحساسة لتقدير حامض ترانيكزاميك بهيئته النقية وفي مستحضراته

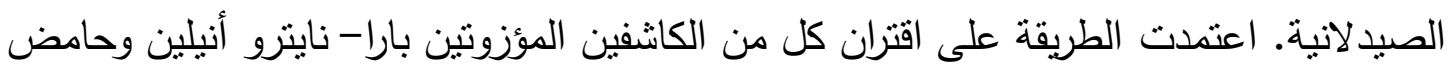

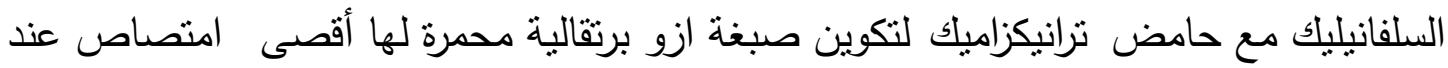
• ror نانوميتز وكانت حدود قانون بير بين (0.1-7.5) مايكروغرام/مللتر والامتصاصية المولارية

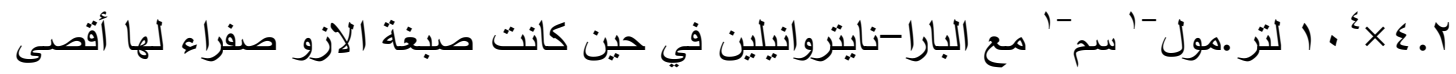

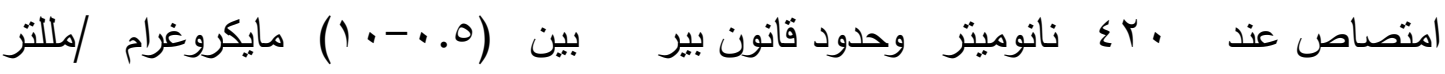

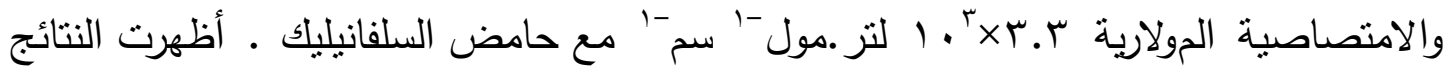
عدم حدوث تداخل في الطريقة المطورة من قبل بعض المضافات الصيدلانية وطبقت الطريقة

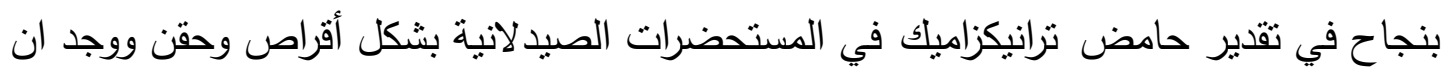
الطريقة متفقة مع المحتوى الأصيل للمستحضرات الصيدلانية وكذللك مع طريقة الإضافة القياسية.

\begin{abstract}
A simple and sensitive spectrophotometric method was developed for the determination of tranexamic acid in bulk and pharmaceutical preparations. The method is based on the coupling of each of diazotised p-nitroaniline and diazotised sulphanilic acid with tranexamic acid to form a reddish-orange azo-dye which absorbs maximally at $520 \mathrm{~nm}$ with diazotised p-nitroaniline. Beer's law was obeyed within (0.1-7.5) ppm with a molar absorptivity $4.2 \times 10^{4} 1 . \mathrm{mole}^{-1} \cdot \mathrm{cm}^{-1}$ and yellow azo-dye which absorbs maximally at $420 \mathrm{~nm}$ with diazotised sulphanilic acid.Beer's law
\end{abstract}


was obeyed within (0.5-10) ppm with a molar absorptivity $3.3 \times 10^{3}$ 1. mole ${ }^{-1} \cdot \mathrm{cm}^{-1}$. All variables were studied to optimise the reaction conditions. No interference was observed in the presence of common pharmaceutical excipients. The validity of method was tested by analyzing tranexamic acid in its pharmaceutical preparations and good recoveries were obtained.

\section{Introduction}

Tranexamic acid [(trans)-4-(aminomethyl)cyclohexane-1carboxylic acid], a synthetic lysine analog, is a competitive inhibitor of plasmin and plasminogen (1). Prophylactic administration of tranexamic acid decreases blood loss and blood transfusion requirements in cardiac surgery patients(2,3). The drug reduces postoperative blood losses and transfusion requirements in a number of types of surgery, with potential cost and tolerability advantages over aprotinin, and appears to reduce rates of mortality and urgent surgery in patients with upper gastrointestinal hemorrhage (4). Several methods have been reported for the determination of tranexamic acid including capillary electrophoresis (5), HPLC (6-12), liquid chromatography (13-15), atomic absorption spectrometry (16), gas chromatography (17), fluorometry (18) and spectrophotometry (19-27). Among the various methods available for the determination of the drug, spectrophotometry continues to be very popular, because of its simplicity, specificity and low cost. To the best knowledge, there are no spectrophotometric methods for tranexamic determination via diazotisation reaction described in the literature to date. Therefore, this study presents new spectrophotometric methods for the determination of tranexamic acid in pure and pharmaceutical preparation. The methods based on the coupling of tranexamic acid in basic medium with two diazotised reagents, p-nitroaniline and sulphanilic acid to form colored azo-dye measured spectrophotometrically.

\section{Experimental}

\section{Apparatus}

All spectral and absorbance measurements were carried out on a shimadzu UV-Visible digital double beam spectrophotometer with 1-cm matched quartz cells.

\section{Reagents}

All chemicals used were of analytical grade and used without further purification.

Standard solution of tranexamic acid $(100 \mu \mathrm{g} / \mathrm{ml})$ was prepared by dissolving $0.01 \mathrm{~g}$ of pure drug in distilled water and then diluted to the mark in a $100 \mathrm{ml}$ volumetric flask. 
Sodium hydroxide solution (1N) was prepared by dissolving $4 \mathrm{~g}$ of sodium hydroxide (Fluka) in distilled water and then diluted to the mark in a100ml volumetric flask.

Diazotised sulphanilic acid solution (30mM) was prepared by dissolving $0.519 \mathrm{~g}$ of sulphanilic acid (Fluka) in $75 \mathrm{ml}$ distilled water then $1.35 \mathrm{ml}$ of concentrated $\mathrm{HCl}$ (Fluka) was added and the solution is heated. The mixture is transferred to a $100 \mathrm{ml}$ volumetric flask and cooled to $\approx 5^{\circ}$ C.A $0.207 \mathrm{~g}$ of sodium nitrite (Fluka) is added and volume completed to $100 \mathrm{ml}$ with addition of cooled distilled water. This solution is stored in the darkness over ice and used after 15 minutes. This solution when kept in the refrigerator is stable for at least 3 days (28).

Diazotised p-nitroaniline solution (20mM) was prepared by dissolving $0.276 \mathrm{~g}$ of p-nitroaniline (Fluka) in $75 \mathrm{ml}$ distilled water then $1.35 \mathrm{ml}$ of concentrated $\mathrm{HCl}$ was added and the solution is heated. The mixture is transferred to $100 \mathrm{ml}$ volumetric flask and cooled to $\approx 5 \mathrm{c}$. A $0.138 \mathrm{~g}$ of sodium nitrite is added and the mixture is stirred for 5 minutes and the volume completed to $100 \mathrm{ml}$ with addition of cooled distilled water. This solution is stored in the darkness over ice and used after 15 minutes. This solution when kept in the refrigerator is stable for at least 3 days (29).

Aminocaprol tablets solution ten tablets of aminocaprol were weighed and finally powdered using a mortar.A weighed amount of the powder equivalent to $500 \mathrm{mg}$ of the pure drug was dissolved in $10 \mathrm{ml}$ of ethanol and made up to $100 \mathrm{ml}$ with distilled water into a volumetric flask.The resulting solution was shaked well and filtrated. A sample of $100 \mu \mathrm{g} / \mathrm{ml}$ of aminocaprol was taken and the measurement was carried out as described under recommended procedure.

Exacyl injection the contents of five ampoules (each one contains $500 \mathrm{mg}$ per $5 \mathrm{ml}$ ) were mixed and a $5 \mathrm{ml}$ was accurately transferred into a $100 \mathrm{ml}$ volumetric flask and diluted to the mark with distilled water. An accurate volume was appropriately diluted to get $100 \mu \mathrm{g} \mathrm{ml}^{-1}$ of tranexamic acid solution and treated as described under the recommended procedure.

\section{Recommended Procedure for Calibration Curve with Diazotised Sulphanilic Acid}

Aliquots of working tranexamic acid standard solution containing (12.5-250) $\mathrm{\mu g}$ were transferred into a series of $25 \mathrm{ml}$ volumetric flasks. To each flask, $2 \mathrm{ml}$ of $(30 \mathrm{mM})$ diazotised sulphanilic acid and $2 \mathrm{ml}$ of (1N) sodium hydroxide were added and the mixture was diluted to the mark with distilled water and mixed well. The absorbance values were measured at $420 \mathrm{~nm}$ after 5 minutes from final addition against a reagent blank which was treated similarly Fig.1 shows the calibration curve which indicates that Beer's law is obeyed over the concentration range $(0.5-10) \mu \mathrm{g} / \mathrm{ml}$. 


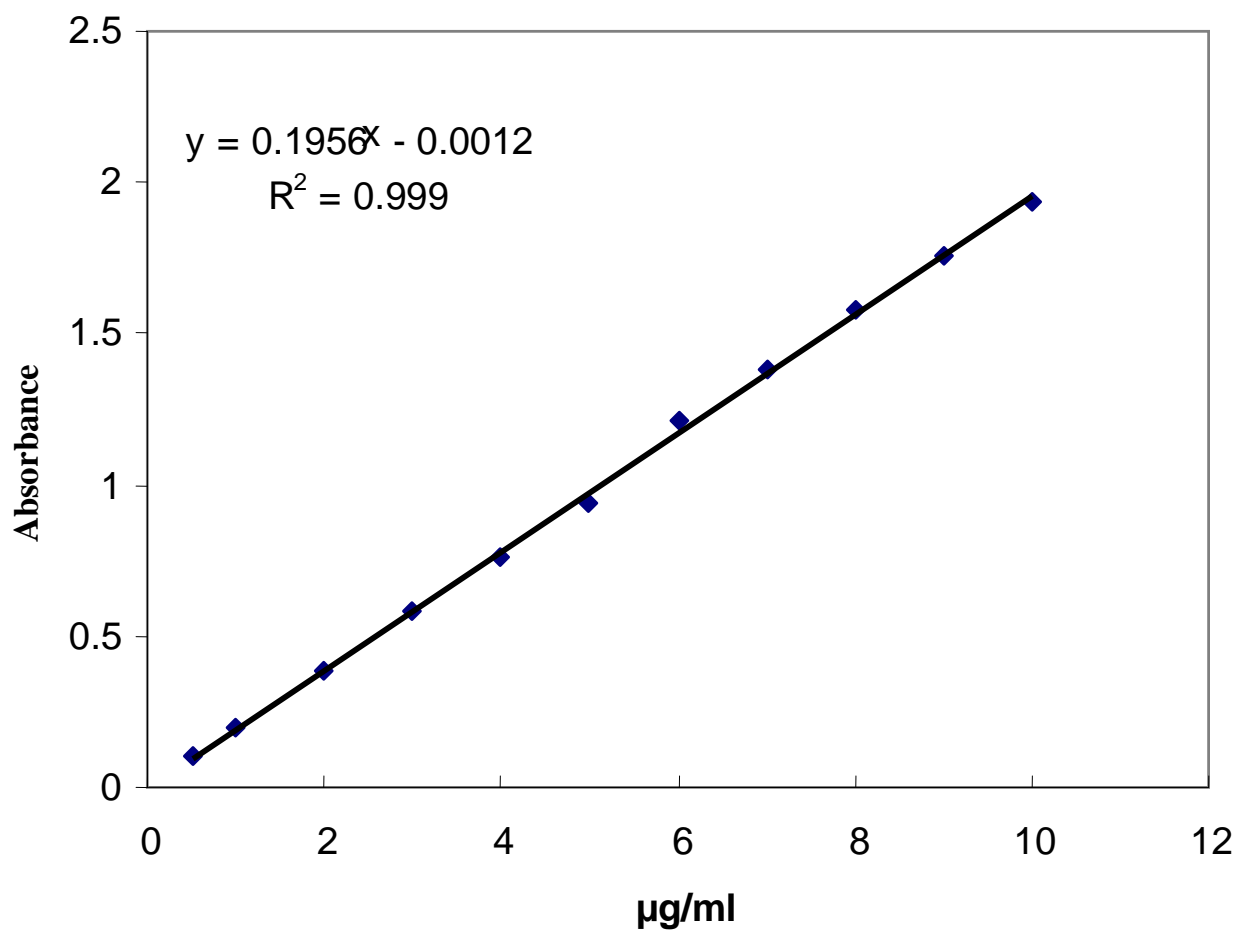

Fig. 1. Calibration graph for the determination of tranexamic acid with diazotised sulphanilic acid

\section{Recommended Procedure for Calibration Curve with Diazotised p-nitroaniline}

Aliquots of working tranexamic acid standard solution containing (2.5-187.5) $\mu \mathrm{g}$ were transferred into a series of $25 \mathrm{ml}$ volumetric flasks. To each flasks, $3 \mathrm{ml}$ of $(20 \mathrm{mM})$ diazotised p-nitroaniline and $2.5 \mathrm{ml}$ of $(1 \mathrm{~N})$ sodium hydroxide were added and the mixture was diluted to the mark with distilled water and mixed well. The absorbance values were measured at $520 \mathrm{~nm}$ after 10 minutes from final addition against a reagent blank which was treated similarly. Fig. 2 shows the calibration curve which indicates that Beer's law is obeyed over the concentration range $(0.1-7.5) \mu \mathrm{g} / \mathrm{ml}$.

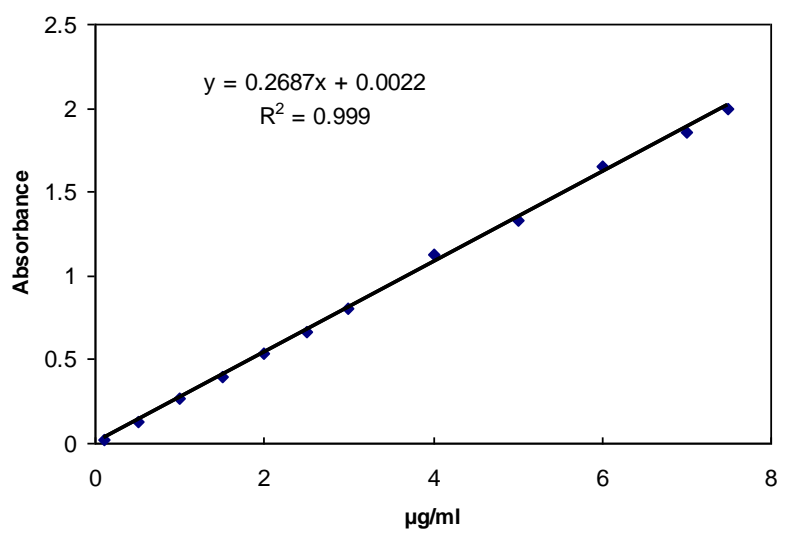

Fig. 2. Calibration graph for the determination of tranexamic acid with diazotised p-nitroaniline 


\section{Optimization of Variables}

For the subsequent experiments, $25 \mu \mathrm{g}$ of tranexamic acid was taken in $25 \mathrm{ml}$ final volumes and absorbance measurements were performed at $420,5 r 0 \mathrm{~nm}$.

\section{Effect of diazotised reagent concentration}

The effect of varying concentration of diazotised sulphanilic acid and diazotised p-nitroaniline was investigated. It was found that diazotised sulphanilic acid $(30 \mathrm{mM})$ and diazotised p-nitroaniline $(20 \mathrm{mM})$ showed highest values of absorbance for the azo-dye formed (Table 1). Therefore, these concentrations were recommended for all subsequent measurements.

Table 1. Effect of diazotised reagent concentration

\begin{tabular}{|c|c|c|c|c|}
\hline \multicolumn{5}{|c|}{ Absorbance/mM of diazotised p-nitroaniline } \\
\hline $5 \mathrm{mM}$ & $10 \mathrm{mM}$ & $15 \mathrm{mM}$ & $20 \mathrm{mM}$ & $25 \mathrm{mM}$ \\
\hline $\mathrm{A}$ & $\mathrm{A}$ & $\mathrm{A}$ & $\mathrm{A}$ & $\mathrm{A}$ \\
\hline 0.151 & 0.165 & 0.169 & 0.181 & $\cdot .100$ \\
\hline \multicolumn{5}{|c|}{ Absorbance/mM of diazotized sulphanilic acid } \\
\hline $10 \mathrm{mM}$ & $20 \mathrm{mM}$ & $30 \mathrm{mM}$ & $40 \mathrm{mM}$ & $50 \mathrm{mM}$ \\
\hline $\mathrm{A}$ & $\mathrm{A}$ & $\mathrm{A}$ & $\mathrm{A}$ & $\mathrm{A}$ \\
\hline 0.092 & 0.121 & 0.155 & 0.150 & 0.150 \\
\hline
\end{tabular}

\section{Effect of base.}

The preliminary experimental investigations have shown that diazotised sulphanilic acid and diazotised p-nitroaniline gave colored dye of high intensity with tranexamic acid in alkaline medium,therefore the coupling reaction has been carried out with different bases and the results show that sodium carbonate and sodium bicarbonate gave colored blank reagent with sulphanilic acid and unstable azo-dye with p-nitroaniline, whereas $(2.5,2) \mathrm{ml}$ of $(1 \mathrm{~N})$ sodium hydroxide solution gave highest value of absorbance with diazotised p-nitroaniline and diazotised sulphanilic acid, respectively for the azo-dye formed [Tables $(2,3)]$. Therefore, 2 and $2.5 \mathrm{ml}$ of $(1 \mathrm{~N})$ sodium hydroxide for each diazotised sulphanilic acid and diazotised p-nitroaniline were recommended for all subsequent measurements.

Table 2. Effect of base with diazotised sulphanilic acid

\begin{tabular}{|c|c|c|c|c|c|c|c|}
\hline \multirow{2}{*}{ Base used $(1 \mathrm{~N})$} & \multirow{2}{*}{ Variable } & \multicolumn{5}{|c|}{ Absorbance / $\mathrm{ml}$ of base used } & \multirow{2}{*}{ pH Range } \\
\hline & & 1.9 & 1.0 & $r_{.} \cdot$ & r.o & r. & \\
\hline \multirow{2}{*}{$\mathrm{NaOH}$} & A & 0.155 & 0.161 & 0.173 & 0.161 & 0.155 & \multirow{2}{*}{ 11.56-12.12 } \\
\hline & $\Delta \lambda_{\mathrm{nm}}$ & $1 \% 0$ & $1 \pi \mu$ & 114 & $11 \% 0$ & $1 \% \varepsilon$ & \\
\hline \multirow{2}{*}{$\mathrm{KOH}$} & A & 0.141 . & 0.140 & $. .10 \leqslant$ &. $.1 T \mathrm{r}$ & .1 .0 & \multirow{2}{*}{$\begin{array}{l}11.199 \\
12.24\end{array}$} \\
\hline & $\Delta \lambda_{\mathrm{nm}}$ & TKT & Tr. & 110 & $1 \cdots$ & NY & \\
\hline \multirow{2}{*}{$\mathrm{Na}_{2} \mathrm{CO} 3$} & A & \multicolumn{5}{|c|}{ The blanks were colored } & \\
\hline & $\Delta \lambda_{\mathrm{nm}}$ & & & & & & \\
\hline \multirow{2}{*}{$\mathrm{NaHCO} 3$} & $\mathrm{~A}$ & \multicolumn{5}{|c|}{ The blanks were colored } & \\
\hline & $\Delta \lambda_{\mathrm{nm}}$ & & & & & & \\
\hline
\end{tabular}


Table 3. Effect of base with diazotised p-nitroaniline

\begin{tabular}{|c|c|c|c|c|c|c|c|}
\hline \multirow{2}{*}{ Base used (1N) } & \multirow{2}{*}{ Variable } & \multicolumn{5}{|c|}{ Absorbance $/ \mathrm{ml}$ of base used } & \multirow{2}{*}{ pH Range } \\
\hline & & 1.0 & 1.0 & r.e & Y.o & $\Gamma \cdot$ & \\
\hline \multirow{2}{*}{$\mathrm{NaOH}$} & A &. .111 &. .190 & 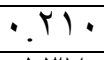 & $\cdot .17$ & $\cdot r^{\prime} \cdot$ & \multirow{2}{*}{$11.77-12.15$} \\
\hline & $\Delta \lambda_{\mathrm{nm}}$ & 149 & THK & ITV & $1 \varepsilon$. & 1140 & \\
\hline \multirow{2}{*}{$\mathrm{KOH}$} & A & .11. & $\cdot{ }^{\wedge 1}$ &. $.1 \mathrm{VV}$ &. .187 &. $.1 \%$ & \multirow{2}{*}{$11.79-12.29$} \\
\hline & $\Delta \lambda_{\mathrm{nm}}$ & IKV & Iro & ITV & IYA & IT. & \\
\hline \multirow{2}{*}{$\mathrm{Na}_{2} \mathrm{CO} 3$} & A & \multicolumn{5}{|c|}{ Unstable azo dye } & \\
\hline & $\Delta \lambda_{\mathrm{nm}}$ & & & & & & \\
\hline \multirow{2}{*}{$\mathrm{NaHCO} 3$} & $\mathrm{~A}$ & \multicolumn{5}{|c|}{ Unstable azo dye } & \\
\hline & $\Delta \lambda_{\mathrm{nm}}$ & & & & & & \\
\hline
\end{tabular}

\section{Effect of diazotised reagent amount}

The effect of various amounts of diazotised sulphanilic acid and diazotised p-nitroaniline were investigated. It was found that $2 \mathrm{ml}$ of $30 \mathrm{mM}$ of diazotised sulphanilic acid and $3 \mathrm{ml}$ of $20 \mathrm{mM}$ of diazotised pnitroaniline showed the highest value of absorbance for the azo-dye formed (Table 4). Therefore, these amounts were recommended for all subsequent measurements.

Table 4. Effect of diazotised reagent amount

\begin{tabular}{|c|c|c|c|}
\hline $\begin{array}{c}\text { Ml of diazotised } \\
\text { sulphanilic acid } \\
(30 \mathrm{mM})\end{array}$ & Absorbance & $\begin{array}{l}\text { Ml of diazotised p- } \\
\text { nitroaniline }(20 \mathrm{mM})\end{array}$ & Absorbance \\
\hline 1 &. $.1 \mathrm{~V}$ & $T$ &., 10 \\
\hline r & .189 & r & . YYY \\
\hline r & .18 & r & . \\
\hline$\varepsilon$ & .170 & $\varepsilon$ &. YYV \\
\hline 0 & .175 & 0 & $\cdot Y Y I$ \\
\hline
\end{tabular}

\section{Effect of time on color development}

The effect of time on the development and stability period of the colored dye was investigated under the optimum conditions. From the experimental data, it has been noticed that the azo-dye with diazotised sulphanilic acid reached maximum absorbance after final addition and remains stable at least for 70 minutes, whereas the azo-dye with diazotised p-nitroaniline reached maximum absorbance after 5 minutes, but remains stable for another 80 minutes (Table 5).

Table 5. Effect of time on color development

\begin{tabular}{|c|c|c|c|c|c|c|c|c|c|c|c|}
\hline \multicolumn{12}{|c|}{ Tranexamic acid with diazotised sulphanilic acid } \\
\hline $\begin{array}{l}\text { Minute/ } \\
\text { standing time }\end{array}$ & 0 & 5 & 10 & 20 & 30 & 40 & 50 & 60 & 70 & 80 & 90 \\
\hline Absorbance & 0.179 & $\cdot r \cdot \cdot$ & 0.200 & 0.201 & 0.200 & 0.199 & 0.201 & 0.199 & 0.198 & 0.190 & 0.19 \\
\hline \multicolumn{12}{|c|}{ Tranexamic acid with diazotised p-nitroaniline } \\
\hline $\begin{array}{l}\text { Minute/ } \\
\text { standing time }\end{array}$ & 0 & 5 & 10 & 20 & 30 & 40 & 50 & 60 & 70 & 80 & 90 \\
\hline Absorbance & 0.231 & 0.269 & $\cdot r 70$ & $\cdot r V$. & . หr9 & $\cdot r V$. & .479 & . r49 & $\cdot r V$. & $\cdot r \sigma^{\wedge}$ & $\cdot r 60$ \\
\hline
\end{tabular}




\section{Effect of surfactant}

The results indicated that addition of different types with different amount, of surfactants gave no useful effect. Therefore, it has been recommended to eliminate their use in the subsequent experiments.

\section{Order of addition reagents}

To obtain optimum results, the order of addition of reagents should be followed as given under the general procedure, otherwise a loss in color intensity was observed.

\section{Final absorption spectra}

When tranexamic acid is treated according to the recommended procedure, the absorption spectra for the dyes from diazotised sulphanilic acid and diazotised p-nitroaniline with tranexamic acid show maximum absorptions at $420 \mathrm{~nm}$ and $520 \mathrm{~nm}$, respectively [Fig.(3,4)]. The reagent blanks practically show negligible absorbances at these wavelengths.

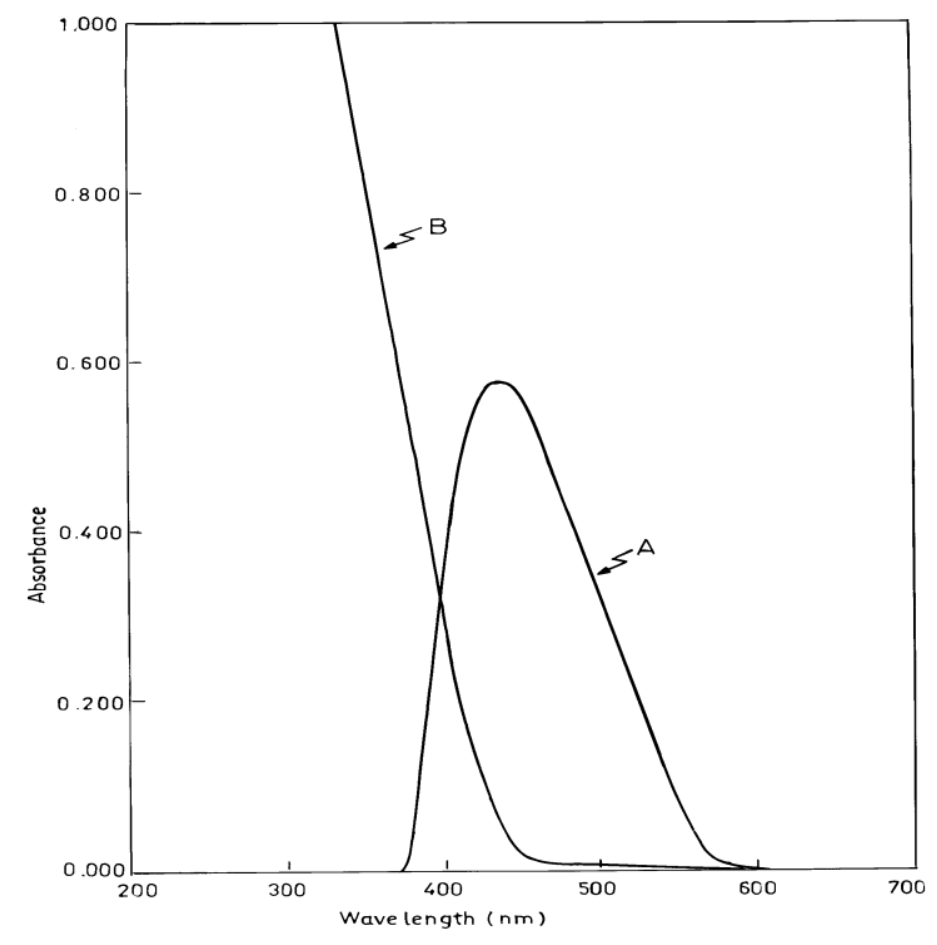

Fig 3. Absorption spectra of $3 \mu \mathrm{g} \mathrm{ml}^{-1}$ of tranexamic acid measured against reagent blank (A) and the reagent blank measured against distilled water (B) with diazotised sulphanilic acid 


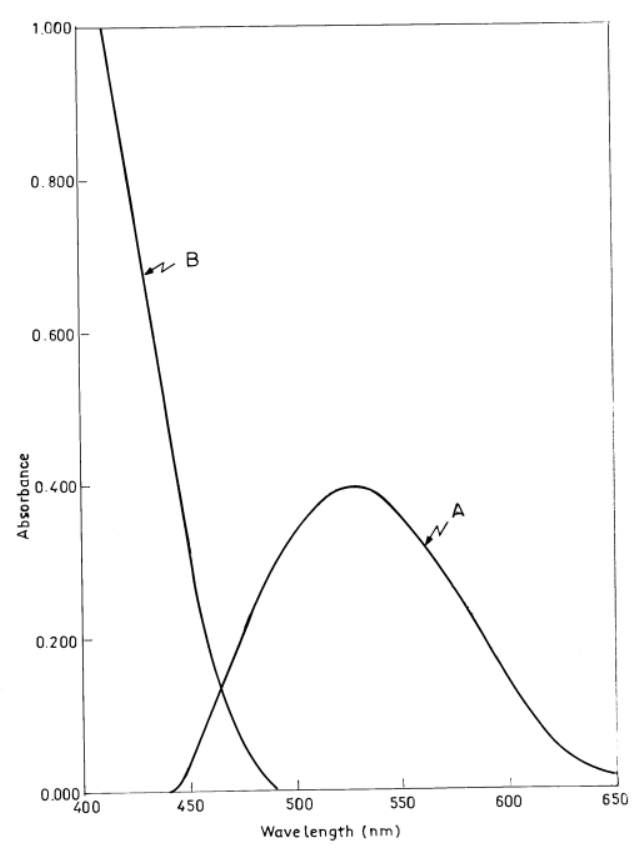

Fig. ؟. Absorption spectra of $3 \mu \mathrm{g} \mathrm{m}^{-1}$ of tranexamic acid measured against reagent blank (A) and the reagent blank measured against distilled water (B) with diazotised p-nitroaniline

\section{Accuracy and precision}

Two different concentrations of tranexamic acid are used with diazotised sulphanilic acid and diazotised p-nitroaniline in the determination of the accuracy and precision of the calibration curve, the results shown in (Table 6) indicate that the calibration curve has good accuracy and precision.

Table 6. Accuracy and precision

\begin{tabular}{|c|c|c|}
\hline $\begin{array}{c}\text { Amount of tranexamic } \\
\text { acid taken } \mu \mathrm{g} / \mathrm{ml} \text { with } \\
\text { PNA }\end{array}$ & ${ }^{*}$ Recovery(C) & $\operatorname{RSD}(\%)$ \\
\hline 1 & I.T.rA & $1 . Y V$ \\
\hline$r$ & $q V . V Y$ & $.0 \mathrm{~V}$ \\
\hline $\begin{array}{l}\text { Amount of tranexamic } \\
\text { acid taken } \mu \mathrm{g} / \mathrm{ml} \text { with } \\
\text { sulphanilic acid }\end{array}$ & ${ }^{*}$ Recovery(c\%) & RSD(c/o) \\
\hline$\varepsilon$ & $90 . V$ & ז. . \\
\hline 7 & $1 \cdot Y .1 \leq$ & 1.91 \\
\hline
\end{tabular}

*Average of five determinations

\section{Nature of the dye product.}

The stoichiometry of the reaction was studied applying Job's method of continuous variations (30). The result obtained [fig. $(5,6)$ ] show that a $1: 1$ drug to the two analytical diazotised reagents were formed. 


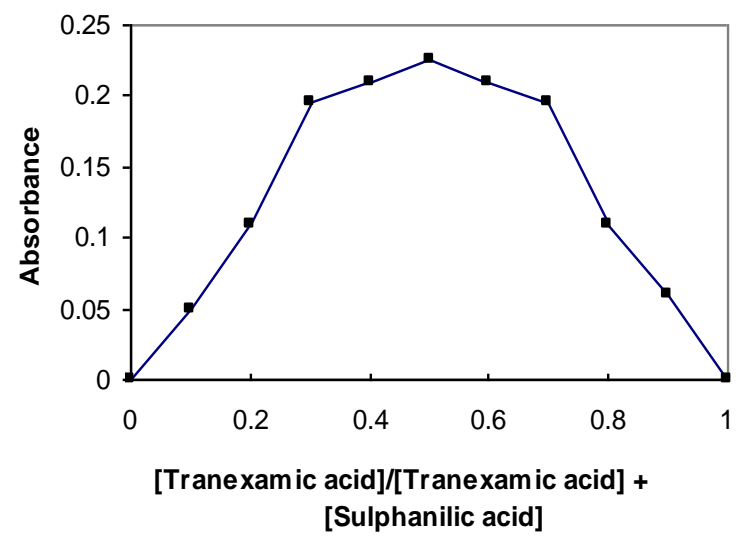

Fig. 5.Job's plot of tranexamic acid with diazotised sulphanilic acid

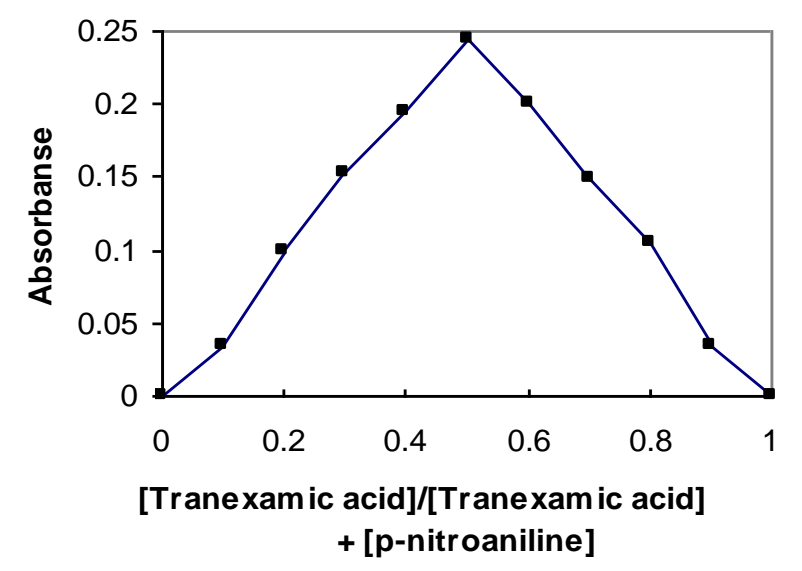

Fig. 6. Job's plot of tranexamic acid with diazotized p-nitroaniline

Therefore, the formation of yellow dye with sulphanilic acid and reddish dye with p-nitroaniline may probably occur as shown in the following reaction scheme $(r 1)$ :

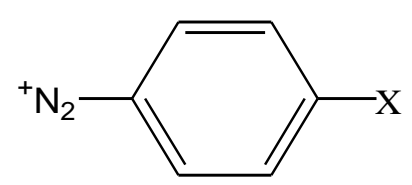

Diazotised reagent

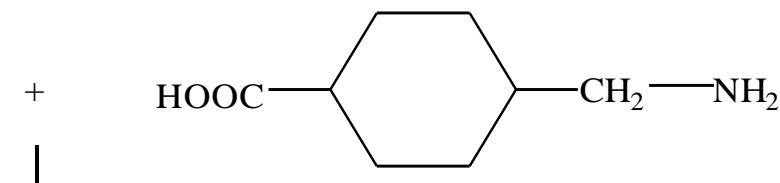

$\mathrm{OH}^{-}$

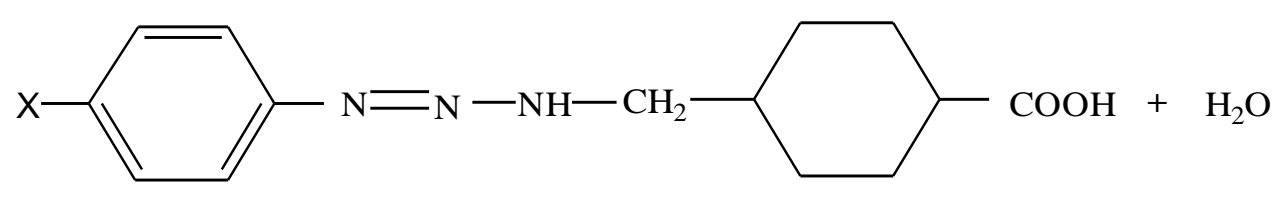

$$
\mathrm{X}=\mathrm{HSO}_{3} \text { or } \quad-\mathrm{NO}_{2}
$$

\section{Interference}

The effect of some excipients which often accompany pharmaceutical preparations was studied by addition of three different amounts to $2 \mathrm{ppm}$ tranexamic aid. Experimental results showed that there was no interference from foreign compounds up to 100 fold excess. Typical results are given in (Table 7). 
Table 7: Effect of foreign compounds

\begin{tabular}{|c|c|c|c|c|c|}
\hline \multirow{2}{*}{$\begin{array}{c}\text { Foreign } \\
\text { compound with } \\
\text { diazotised } \\
\text { sulphanilic acid }\end{array}$} & \multicolumn{2}{|c|}{ Recovery(\%) } & \multirow{2}{*}{$\begin{array}{c}\text { Foreign } \\
\text { compound with } \\
\text { diazotised p- } \\
\text { nitroaniline }\end{array}$} & \multicolumn{2}{|c|}{ Recovery(\%) } \\
\hline & $\begin{array}{l}10 \text { Fold } \\
\text { excess }\end{array}$ & $\begin{array}{c}100 \\
\text { Fold } \\
\text { excess }\end{array}$ & & $\begin{array}{c}10 \text { Fold } \\
\text { excess }\end{array}$ & $\begin{array}{c}100 \\
\text { Fold } \\
\text { excess }\end{array}$ \\
\hline Glucose & 90.0 & 90. & Glucose & 90. & 90.1 \\
\hline Starch & $9 V . Y$ & 97.1 & & 97.1 & 97.1 \\
\hline Lacts & 97. & 97.1 & $\mathrm{La}$ & 96.5 & 90.0 \\
\hline Acacia & 91.1 & $9 \vee .1$ & & 90.0 & 90 \\
\hline Sodium Chloride & 99.4 & 99.4 & Sodium Chloride & 99.4 & 99.0 \\
\hline
\end{tabular}

\section{Analytical applications}

The present method was evaluated by analyzing commercial formulation of tranexamic acid and comparing the results obtained with those obtained by standard addition procedure [Fig. $(7,8)]$. Satisfactory agreement between results was obtained with an acceptable range of error [Tables $(8,9)]$.

Table 8. Assay of tranexamic acid in pharmaceutical preparations with diazotised sulphanilic acid

\begin{tabular}{|c|c|c|c|c|c|}
\hline $\begin{array}{c}\text { Pharmaceutical } \\
\text { preparation }\end{array}$ & $\begin{array}{c}\text { Certified } \\
\text { value(mg) }\end{array}$ & $\begin{array}{c}\text { Amount } \\
\text { Present } \\
\mu \mathrm{g} / \mathrm{ml}\end{array}$ & $\begin{array}{c}\text { Recovery }^{a} \\
\text { (\%) }\end{array}$ & $\begin{array}{c}\text { Average } \\
\text { Recovery } \\
\text { ( } \%)\end{array}$ & $\begin{array}{c}\text { Drug } \\
\text { Content } \\
\text { Found } \\
(\mathrm{mg})\end{array}$ \\
\hline $\begin{array}{l}\text { Aminocaprol } \\
\text { tablets }\end{array}$ & $500 \mathrm{mg}$ & $\varepsilon$ & 97. Yo & \multirow{2}{*}{ 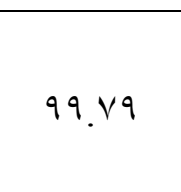 } & ENI. ro \\
\hline Exacyl $^{c}$ injection & $500 \mathrm{mg} / \mathrm{ml}$ & 7 & מז.r.1 & & 017.70 \\
\hline
\end{tabular}

${ }^{\mathrm{a}}$. average of three determinations.

b . marked by Al Shahba Pharmaceutical Labs.- Aleppo-Syria

c. marked by Sanofi-Synthelabo-France

Table 9. Assay of tranexamic acid in pharmaceutical preparations with diazotised p-nitroaniline

\begin{tabular}{|c|c|c|c|c|c|}
\hline $\begin{array}{l}\text { Pharmaceutic } \\
\text { al preparation }\end{array}$ & $\begin{array}{c}\text { Certified } \\
\text { value(mg) }\end{array}$ & $\begin{array}{c}\text { Amount } \\
\text { Present } \\
\mu \mathrm{g} / \mathrm{ml}\end{array}$ & Recovery ( \%) & $\begin{array}{c}\text { Average } \\
\text { Recovery } \\
\text { ( \%) }\end{array}$ & $\begin{array}{l}\text { Drug } \\
\text { Content } \\
\text { Found } \\
(\mathrm{mg})\end{array}$ \\
\hline $\begin{array}{l}\text { Aminocaprol } \\
\text { tablets }\end{array}$ & $500 \mathrm{mg}$ & 1 & $1.0 .$. & \multirow{2}{*}{1.1 .74} & oro \\
\hline $\begin{array}{l}\text { Exacyl } \\
\text { injection }\end{array}$ & $500 \mathrm{mg} / 5 \mathrm{ml}$ & r & q1.r & & $\leqslant 91.70$ \\
\hline
\end{tabular}




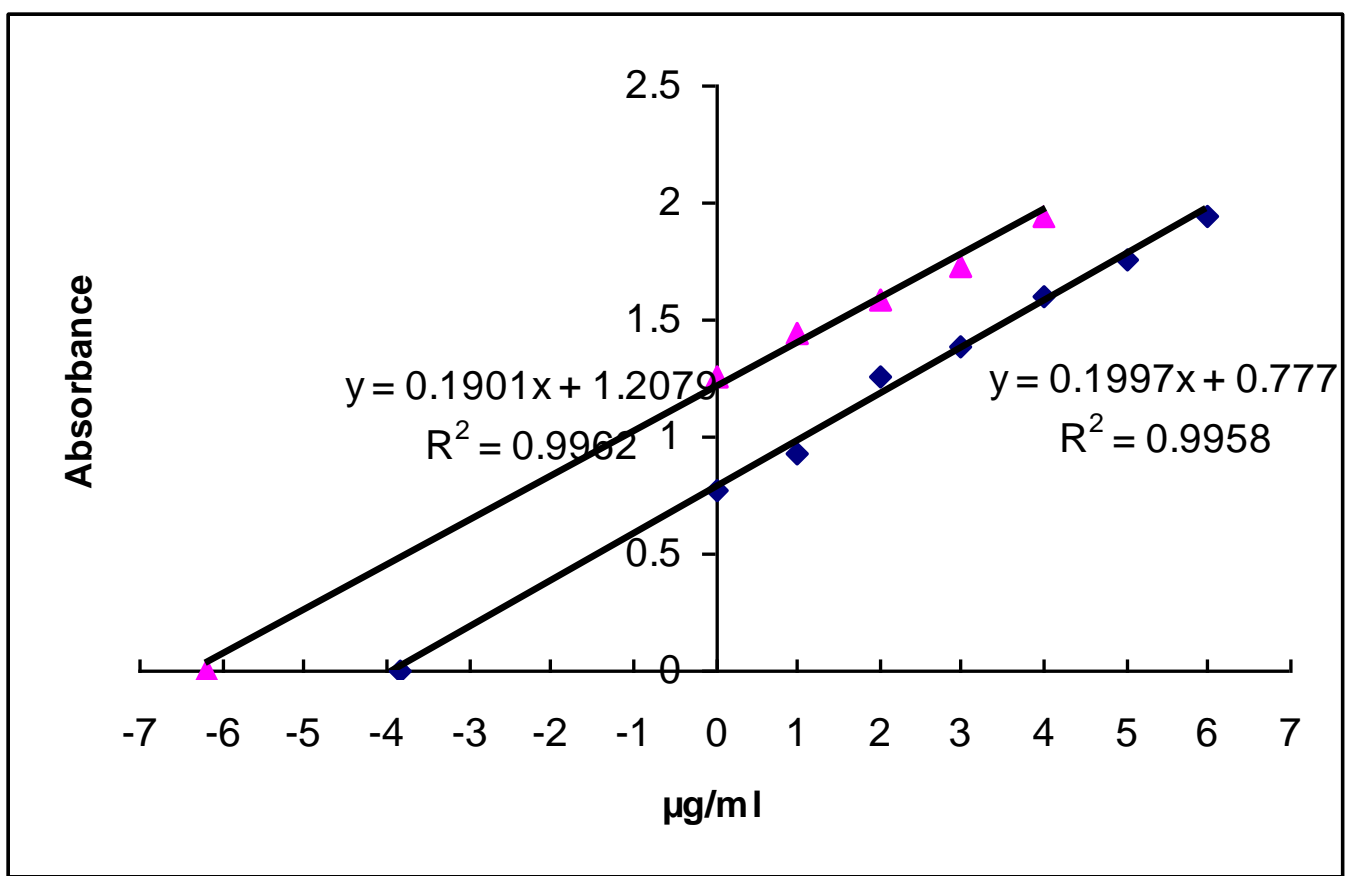

Fig. 7. Assay of tranexamic acid in pharmaceutical preparations with sulphanilic acid by standard addition method

$\Delta$ Standard addition method of $4 \mu \mathrm{g} \mathrm{ml}^{-1}$ using injection with diazotised sulphanilic acid.

- Standard addition method of $6 \mu \mathrm{g} \mathrm{ml}^{-1}$ using tablets with diazotised sulphanilic acid.

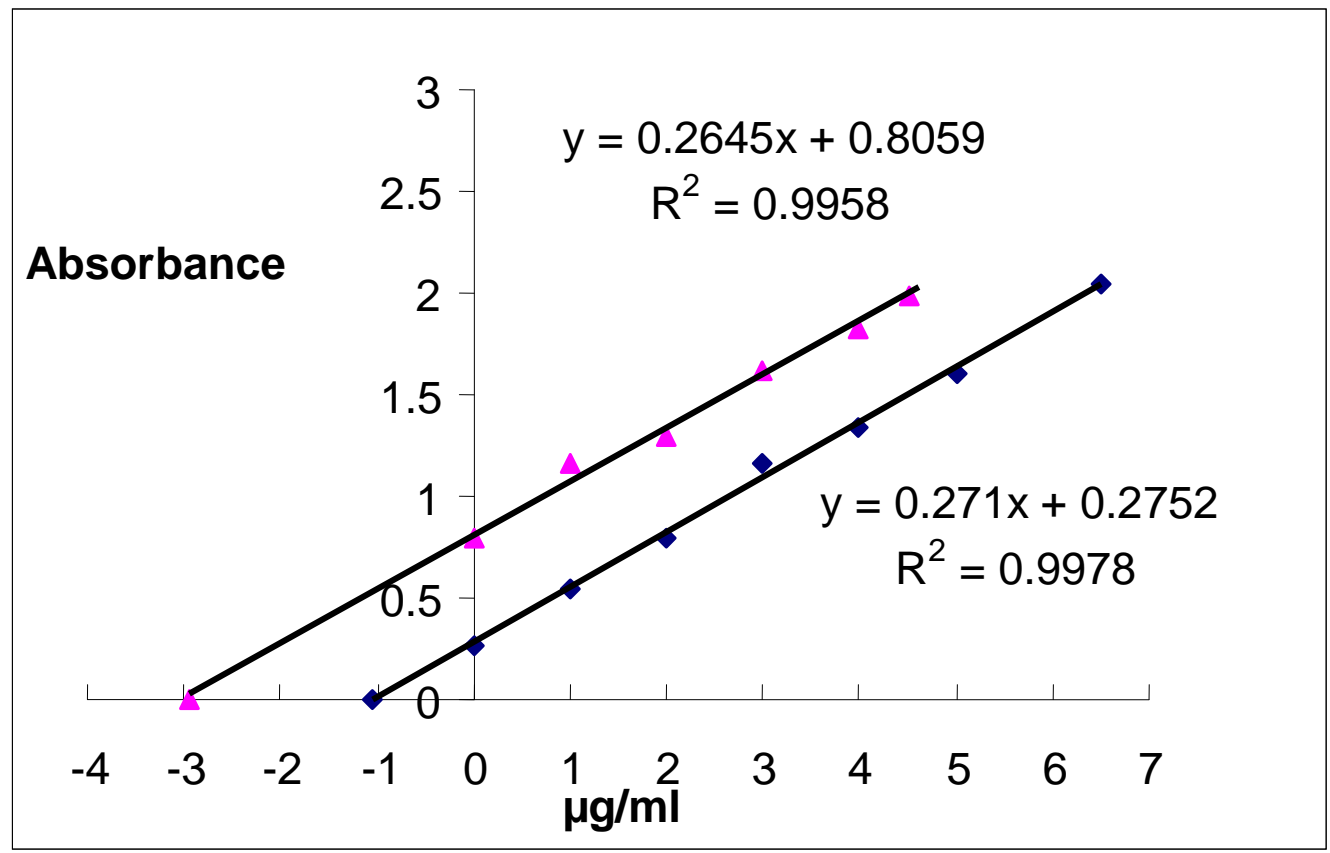

Fig. 8. Assay of tranexamic acid in pharmaceutical preparations with pnitroaniline by standard addition method

A Standard addition method of $1 \mu \mathrm{g} \mathrm{ml}^{-1}$ using injection with diazotised $\mathrm{p}$ nitroaniline.

- Standard addition method of $3 \mu \mathrm{g} \mathrm{ml}^{-1}$ using tablets with diazotised p-nitroaniline. 


\section{Conclusion}

A simple, rapid and sensitive spectrophotometric method for the determination of trace amounts of tranexamic acid has been developed. The method was based on the coupling of tranexamic acid with two diazotised sulphanilic acid and p-nitroaniline in basic medium to form mono azo-dye that is water soluble and stable. The proposed method was applied successfully to some pharmaceutical preparation (tablet, injection).

\section{Reference}

1) Royston D., Int Anesthesiol Clin., 33:155-79 (1995).

2) Laupacis A. and Fergusson D., Anesth Analg., 85:1258- 1267, (1997).

3) Menichetti A., Tritapepe L., and Ruvolo G., J Cardiovasc Surg., 37:401- 407, (1996).

4) Dunn C. J. and Goa. K, Drugs, 57: 1005, (1999).

5) Manabe T., Yamamoto H., and Okuyama T., Electrophoresis., 10:172-177,(1989).

6) Matsubayashi K., Kojima C., Tachizawa H., J. Chromatogr. Biomed Appl., 77:225- 234, (1988).

7) Sato K., Tobita Y., Iwabuchi K., Tanaka S., Anal. Sci., 13:471474, (1997).

8) Xu Z. Z., Chen Z. Z., Yaowu Fenxi Zazhi., 13: 173-175, (1994).

9) Abrahamsson M., J. Pharm. Biomed. Anal., 4:399- 406, (1986).

10) Lacroix C., Levert P., Laine G., Goulle J. P., J. Chromatogr. Biomed Appl., 34: 183-186 (1984).

11) Ghada m., Alaa El-Gindy, Waleed M. M., Chromatographia., 66: 311-317, (2007). Jose F., Mical H., Henk D., Hans, K, Jane L., and Freek A., J. Chromatogra. A.,1157:142- 150,(2007).

12) Chang, O. Q. P. Yin, and Chow M. S. S., J. Chromatogr., B: Anal. Technol. Biomed. Life Sci., 805: 275, (2004).

13) Berniati T., Hosiana N., and Sumarlik K., J. Liquid Chromatogr., 28:3243-3254, (2005).

14) M. Saad, Najma S. Faiza Q. and Farhan A., Chromatographia., 70: 789-795, (2009). A Shalaby, Chin. Pharm. J. [Taipei], 49: 229-235, (1999). 
15) Uehara, T. Hagiwara, Takahashi M., Kamata K., K., Nakayama K. Akiyama, and Naoi Y., Iyakuhin Kenkyu., 18: 142, (1987).

16) Iskender A. and S. Atmaca, Pharmazie., 43: 290,(1988).

17) Atmaca S., Acta Pharm. Turc., 31:115-118, (1989).

18) Iskender G., Atmaca S., Pharmazie., 43: 290, (1988).

19) Atmaca S., Acta Pharm. Turc., 31, 115-118, (1989).

20) Iskender G., Atmaca S., Pharmazie, 43, 290, (1988).

21) Buyuktimkin N., Buyuktimkin S., Acta Pharm. Turc., 27, 78-81, (1985).

22) Mohamed M. E., Abou Enein H. Y., Int. J. Environ Anal. Chem., 19, 19-25, (1984).

23) Wahbi A. A. M., Lotfi E. A., Abou Enein H. Y., Talanta, 31, 7778, (1984).

24) Rizk M. S., Toubar S. S., Sultan M. A., Assaad S. H., Microchim. Acta, 143, 281-285, (2003).

25) Ansari T. M., Raza A., Rehman A. U., Anal. Sci., 21, 1133-1135, (2005).

26) Saad M., Najma S., Farhan A. M. Hashim, and Z. Mirza, J. Molecular Structure, 891,475-480, (2008).

27) Khalifa A. A., Adel M. A., and Hishim E. A., Chem. Pharm. Bull., 55,364-367, (2007).

28) Ramadan, S.A.O., M.Sc. Thesis, Mosul Universty, 68, (2007).

29) Al-Abasi K. M., J. Raf. Sci., 20, 63, (2009).

30) Delevie R., Principles of quantitative chemical analysis, McGrawHill International Edition, Singapore, 498, (1997).

31) Saunders K. H. and Allen R. L. M., Aromatic diazo compounds, $3^{\text {rd }}$ ed., Edward Arnold,UK, 368-369 (1985). 